\title{
Adalékanyag hatása a beton lövedékekkel szembeni ellenállására
}

\section{Bevezetés}

A vasbeton korunk egyik legnépszerübb építőanyaga. Gondos tervezéssel és kivitelezéssel gazdaságosan készíthető, jól és tartósan ellenáll a különböző hatásoknak. Szintén nagy előnye, hogy összetételének változtatásával jól igazítható a szükséges funkciókhoz, így különleges hatásokkal szemben is ellenállóvá tehető (pl. korrozív környezetben, tűzhatás, fagyhatás, koptató hatás, sugárzás esetén). Fontos különleges hatás az ütközés, valamely testnek betonszerkezetbe történő becsapódása: a katonai lövedékeken kívül, ipari épületek esetén, egy használat során eltört turbinalapát, csőtöréskor a nagy energiájú víz, hidak esetén egy oszlopnak ütköző autó, vagy egy extrém szél, illetve tornádó által felkapott tárgy mind becsapódó lövedékké válhat. A felsorolás is jól mutatja, hogy mind becsapódásuk okában, gyakoriságában, mind tulajdonságaikban lényegesen eltérhetnek a szerkezeteket veszélyeztető lövedékek. A következőkben bemutatott kísérletek során a jól szabályozható és pontos vizsgálati körülmények miatt katonai lövedékeket alkalmaztunk, ugyanakkor az eredmények más típusú lövedékek esetére is kiterjeszthetők. A vizsgálatokra a Budapesti Műszaki és Gazdaságtudományi Egyetem Építőmérnöki Kar és a Magyar Honvédség Logisztikai Központ együttműködésében került sor.

\section{BETONOK JELLEMZŐI ÉS VISELKEDÉSÜK}

A beton elsődleges alkotóelemei a cement, víz, adalékanyag (homok, kavics, egyéb különleges adalékanyag), valamint a különböző tulajdonságokat (pl. bedolgozhatóságot, kötési időt stb.) nagyban befolyásoló adalékszerek. A megfelelő alapanyagok, azok keverési arányai (betonreceptúra), a megfelelő keverés, szállítás, bedolgozás és utókezelés (pl. nedvesen tartás) mind nagyban befolyásolják a beton tulajdonságait. A keveréket a szerkezet majdani funkcióinak, a lehetséges hatásoknak a mérlegelésével kell megtervezni. Lövedék becsapódásának kitett betonszerkezetek esetén lényeges, hogy a becsapódás elsődleges hatás-e, amire terveznünk kell (pl. lőterek falai) vagy pl. balesetek során különleges hatásként kell-e vele számolnunk. Első esetben, üzemszerű lövedék becsapódásánál különleges, lövedék- és energiaelnyelő falakat készíthetünk, amelyek fajlagos költsége igen nagy. Abban az esetben, ha különleges, kis valószínűségű hatásként éri a szerkezetet valamilyen lövedék, akkor kiemelten fontosak lehetnek azok a döntések, amelyek nem járnak nagy plusz költségekkel, ugyanakkor növelhetik a becsapódással szembeni ellenállást. A továbbiakban bemutatott betonkeverékekkel ilyen döntések hatásait elemezzük.

1. ábra. Ütközés lokális hatása vasbeton szerkezet esetén:

(a) penetráció, (b) szakadókúpos repedés, (c) mállás (külső oldal), (d) repedés, (e) varasodás (védett oldali mállás), (f) perforáció (Li és társai [2005] alapján)

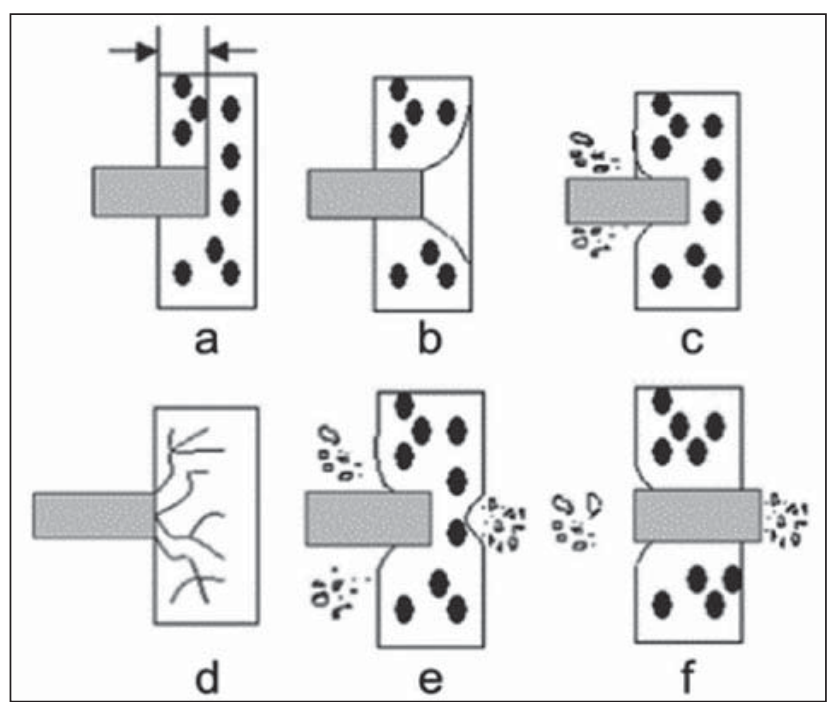

ABSTRACT: During experiments described, resistance of the reinforced concrete against projectiles and impact of projectiles against concrete constructions were examined under well-controllable and precise testing circumstances. Changing the composition of concrete also influenced the results of the experiment. Tests were executed by the Faculty of Civil Engineering of the Budapest University of Technology and Economics in cooperation with the Logistic Centre of the Hungarian Defence Force.

KEY WORDS: reinforced concrete, resistance against projectile, Budapest University of Technology and Economics, Hungarian Defence Force

\footnotetext{
* Egyetemi adjunktus, BME Hidak és Szerkezetek Tanszék. ORCID 0000-0002-8435-3764

** Doktorandusz, BME Építőanyagok és Magasépítés Tanszék. ORCID 0000-0001-5435-4400

*** Mk. ezredes, Phd, MH LK KFTSZO osztályvezető; adjunktus, Nemzeti Közszolgálati Egyetem. ORCID 0000-0003-0449-7678

**** Egyetemi docens, laborvezető, BME Építőanyagok és Magasépítés Tanszék. ORCID 0000-0003-4729-5048

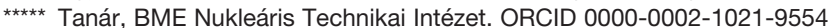


Az 1. ábra kemény lövedék-becsapódás vasbeton falra gyakorolt lehetséges lokális hatásait mutatja, amelyek jellemzően: penetráció, szakadókúp, külső mállás, varasodás (védett oldali mállás), repedések, perforáció. A megengedhető károsodási módok függenek a célszerkezet funkcióitól. Legtöbbször elegendő a perforáció elkerülése, ezzel a fal mögötti helyiség védelme, azonban előfordulhat, hogy a védett térben már varasodás esetén is keletkeznek olyan másodlagos lövedékek (leverődő törmelékdarabok), amelyek hatását el kell kerülni.

A kemény lövedékek becsapódásával szembeni ellenállást a szakirodalomban három jellemzővel mérik, amelyek a penetrációs mélység (a lövedék orrának behatolása az ütközés felőli oldalon), illetve a perforációs és varasodási határvastagság (amelyek a perforáció, illetve varasodás elkerüléséhez szükséges minimális falvastagságok). Ezt a három jellemzőt a szakirodalomban részint elméleti modellekre, részint kísérletekre alapozott fél-empirikus képletek segítségével számítják. Az ilyen formulák hátránya, hogy alkalmazhatóságuk nagyban függ a megalapozó kísérletek paramétertartományától (lövedék méret, sebesség stb.). A meglévő számítási módokat elemzik és hasonlíták össze többek kötözött Kennedy (1976), Teland (1998), Li és társai (2005), valamint Murthy és társai (2010). Az általuk összegyűjtött képletek túlnyomó részében a lövedék jellemzői közül az átmérő, tömeg, sebesség, orralak szerepel, míg a célszerkezet oldaláról csak a beton nyomószilárdsága jelenik meg. A nyomószilárdság a beton egyik legjellemzőbb tulajdonsága, amely alapján minősítik azt, mérése szabványos egytengelyű nyomókísérlettel történik. Felmerül azonban a kérdés, hogy vannak-e olyan betonjellemzők, amelyek nem csak a nyomószilárdságon keresztül befolyásolják a lövedékkel szembeni ellenállást. Cikkünkben az adalékanyag - mint az egyik legfontosabb betonalkotó - kemény lövedékkel szembeni ellenállásra gyakorolt lehetséges hatásait vizsgáljuk.

\section{A VIZSGÁLt BETONKEVERÉKEK, AZ ADALÉKANYAG JELLEMZŐI}

Hazánkban a leggyakrabban alkalmazott adalékanyag a homokos kavics. A beton szilárdulása során az adalékanyag-szemcsék vázat alkotnak, a köztük lévő réseket pedig a megkötött cementkő tölti ki. Az adalékanyag-váz szempontjából nagy fontosságú az adalékanyag méretének eloszlása (szemeloszlás), illetve a maximális adalékanyagméret $\left(d_{\max }\right)$. A szemeloszlás alapvető fontosságú, mivel tömör beton akkor készíthető, ha a nagyobb szemcsék közti réseket minél inkább kitöltik a kisebb szemcsék. Ennek megfelelően a szemeloszlás szabványokban előírt jellemző. A maximális szemnagyság növelése általában javítja a bedolgozhatóságot, a szilárdságot, ugyanakkor a szerkezet méretei, a vasalás mennyisége, illetve az alkalmazott technológia határt szabnak a maximális szemnagyságnak.

A betonanyag egyik legnagyobb hátránya, hogy húzás esetén jelentősen alacsonyabb a teherbírása, mint nyomás esetén. Húzáskor a húzás irányára merőlegesen repedések keletkeznek, amelyek terjedésével a szerkezet akár tönkre is mehet. Az adalékanyag kiemelten fontos lehet a repedések terjedése szempontjából is. Statikus terhelés során a repedések döntően az adalékanyag-szemcsék és a cementkő közti határfelületen, illetve a cementkőben haladnak (Id. 2. ábra). Ezzel szemben nagy sebességű dinamikus terheléskor (pl. lövedékbecsapódás) az adalékszemeken áthalad a repedés, ami jelentősen növelheti a beton ellenállását, hiszen ekkor a nagyobb szilárdságú összetevők tönkremenetele következik be.

$8 \rightarrow$ HADITECHNIKA LII. évf. - 2018/1

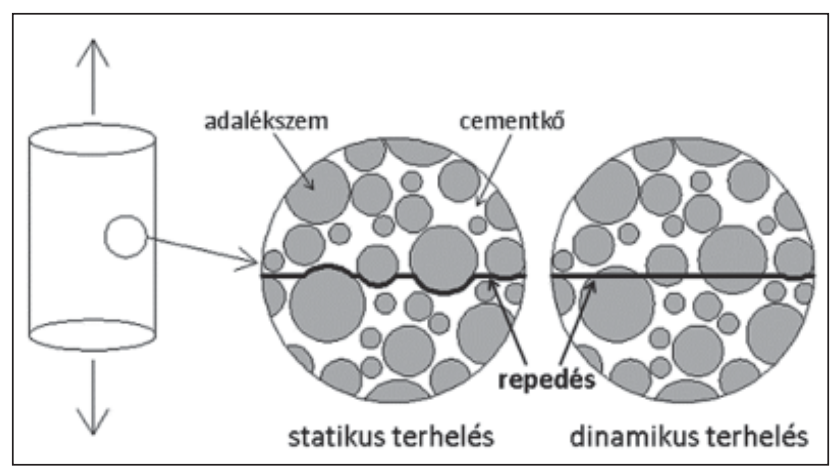

2. ábra. Repedés terjedése statikus és dinamikus húzás esetén (Zielinski [1984] alapján)

Kísérleteinkben az adalékanyag hatását összesen kilenc különböző betonkeverékkel vizsgáltuk, amelyek elsősorban az adalékanyag összetételében tértek el. Normálbeton keverékek (NC - normal concrete) mellett vizsgáltunk mészkőliszt adagolással készült öntömörödő betonkeverékeket (SCC - self compacting concrete), illetve különleges acélsörét adalékanyagot is tartalmazó nehézbeton (HWC - heavy weight concrete) keverékeket. Az öntömörödő betonok esetén a mészkőliszt adagolásával olyan betont hoztunk létre, amely kivitelezéskor tömörítés (vibrálás) nélkül, csupán a saját önsúlyától tömörödik, kitölti a zsaluzatot. A nehézbeton keverékeknél 1-1,7 mm átmérőjű (S390 és S660 jelű) acélsörétet is adagoltunk, aminek elsődlegesen sugárvédelmi szempontból lehet komoly szerepe.

A keverékek esetén háromféle maximális szemnagyságot alkalmaztunk: $4 \mathrm{~mm}$ habarcs-, illetve $8 \mathrm{~mm}$ és $16 \mathrm{~mm}$ maximális szemnagyságú betonkeverékeket. Ezeken kívül egy cementpép keverék is készült, amelyben nem volt adalékanyag. A keverékek későbbiekben alkalmazott jelölése az angol rövidítések mellett a maximális szemnagyságot tartalmazza (pl. NC16: normálbeton 16 mm-es maximális szemnagysággal), az NCO a cementpép keveréket jelöli.

\section{VIZSGÁLATOK}

\subsection{LÖTÉRI PRÓBÁK}

A vizsgálatok során minden betonösszetételből $1 \mathrm{db} 70 \times$ $70 \times 6 \mathrm{~cm}$ méretű lemez készült, amelyekben $4 \mathrm{~mm}$ átmérőjū, két irányban, egymástól $50 \mathrm{~mm}$ távolságban futó acélszálakból álló, kétoldali hálós vasalást is elhelyeztünk a mozgathatóság, szállíthatóság érdekében (3. és 4. ábra). A betonfedés $15 \mathrm{~mm}$-es volt, amelyet távtartók segítségével biztosítottunk. A víz párolgásának csökkentése érdeké-

\section{3. ábra. A lemezekben elhelyezett betonacélháló}

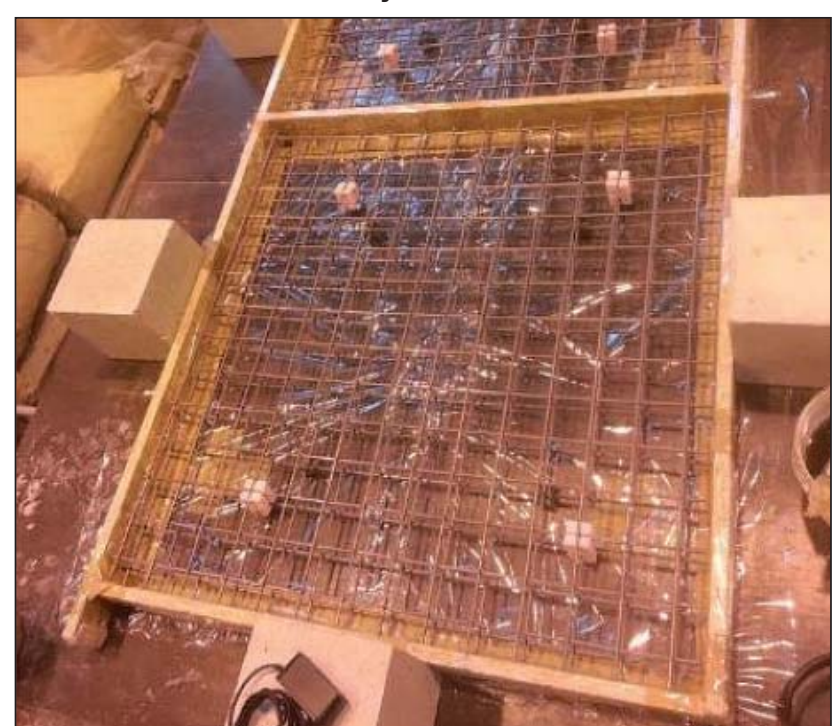



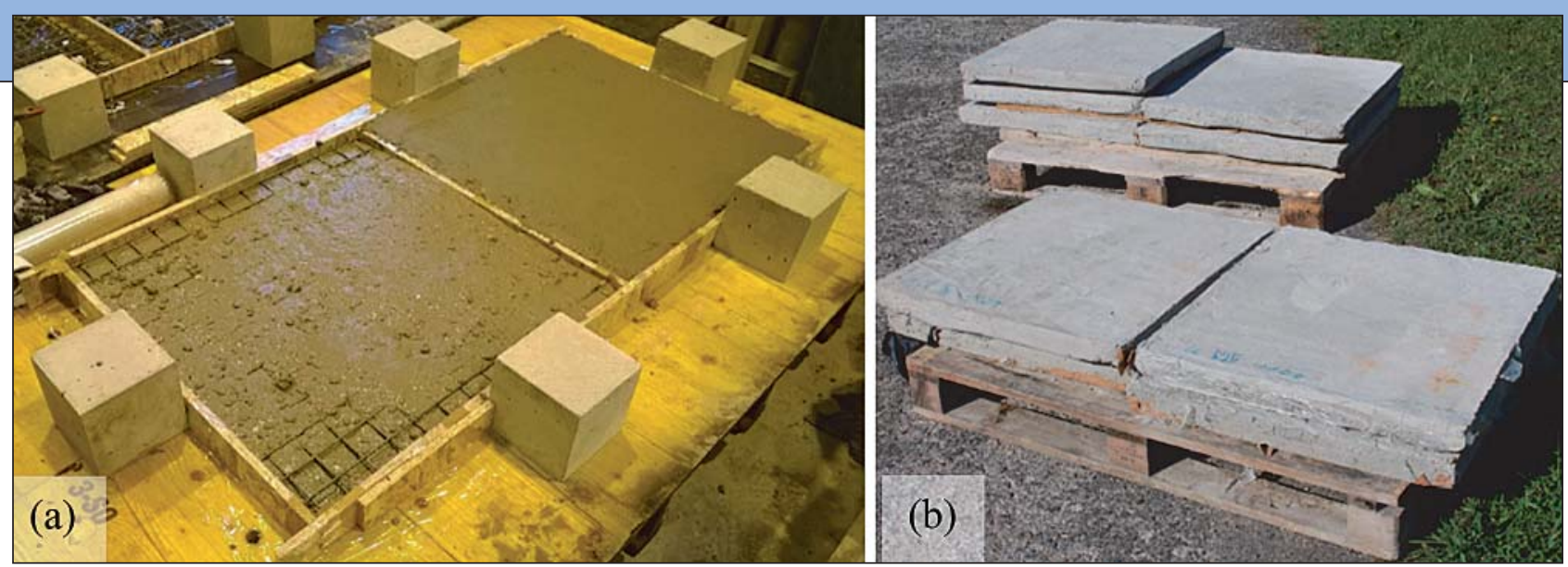

4. ábra. Lőtéri próbákhoz alkalmazott próbatest (a) betonozás közben és (b) elkészült állapotban

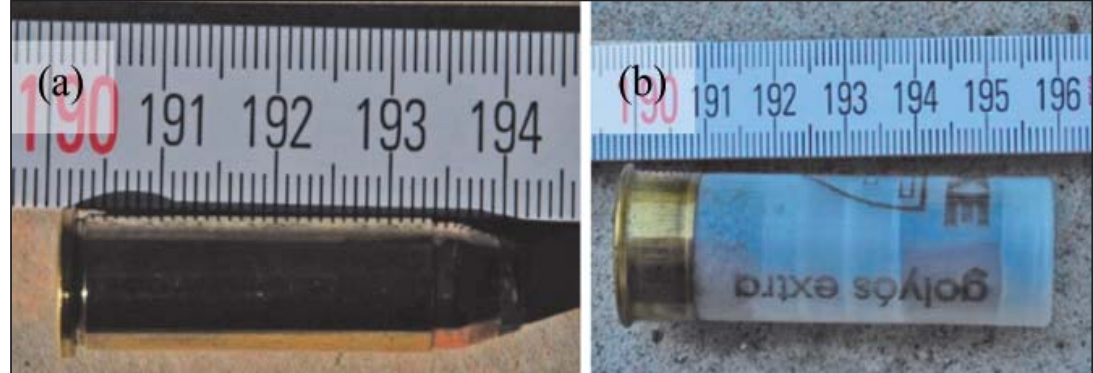

5. ábra. (a) .44 Magnum lőszer és (b) 12/70 Brenneke lőszer

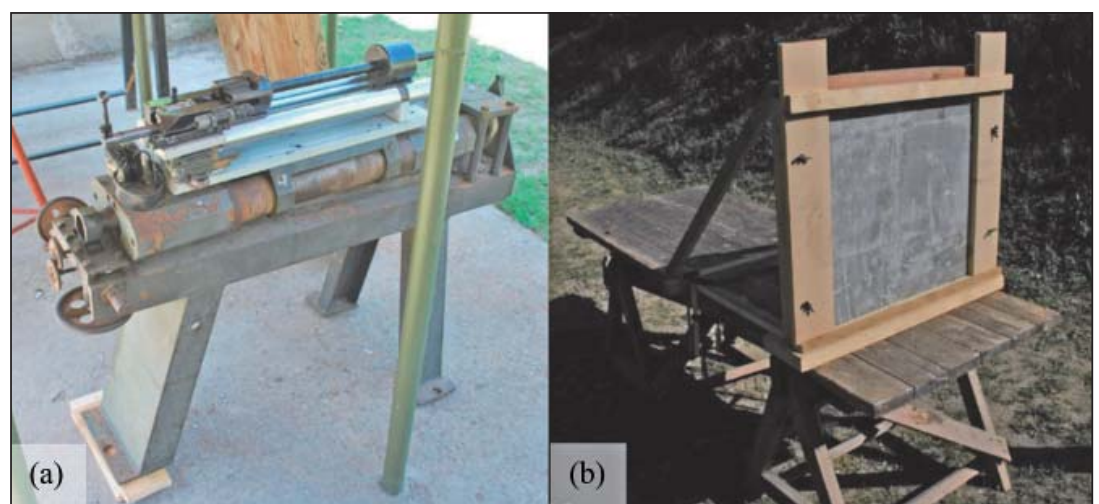

7. ábra. (a) Kilövő bak és (b) a betonlemez megtámasztása

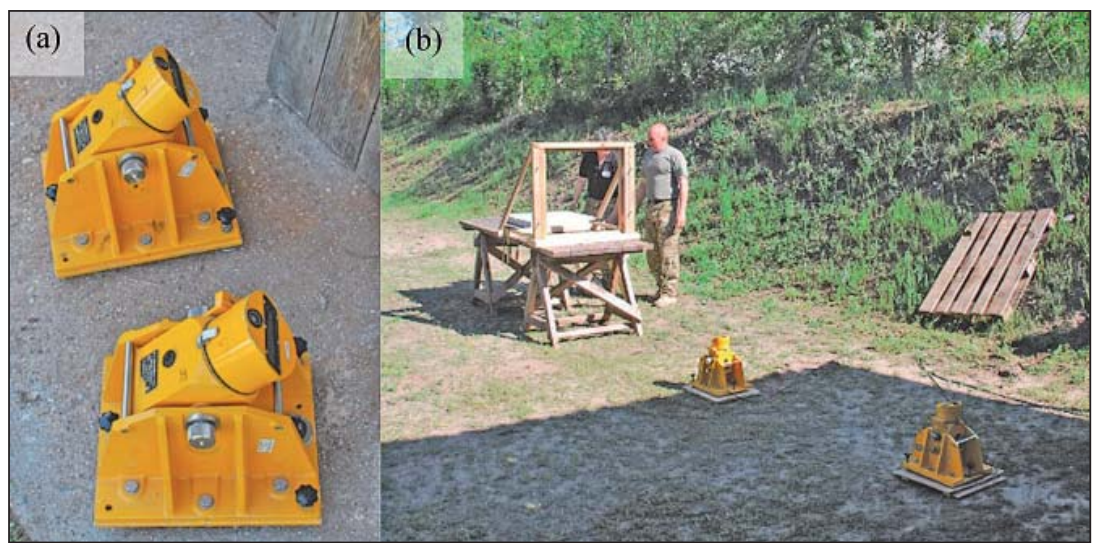

8. ábra. (a) Fotocellás sebességmérök és (b) elhelyezésük a lővonalban

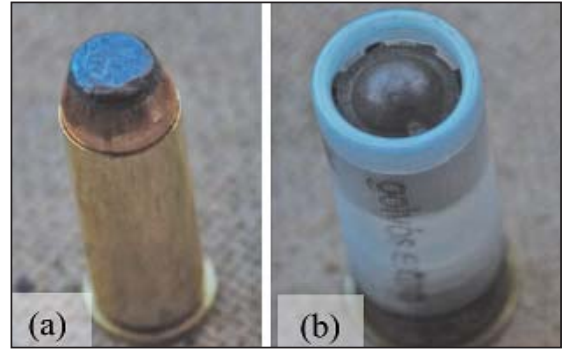

6. ábra. (a) .44 Magnum és (b) 12/70 Brenneke lőszer orrának alakja

A lőtéri próbák során két lövedéktípust alkalmaztunk: .44 Magnum kézilőfegyver-lövedéket, illetve 12/70 kaliberű, vadászlőfegyverbe való gyöngygolyó (a továbbiakban elterjedt nevén Brenneke) lövedéket. Mindkét lövedék ólom anyagú, tompa orrú lövedék. A .44 Magnum lövedék hasított (orrnál nyitott) rézköpenyű, azonban a vékony rézköpeny hatása a vizsgálatok során a tapasztalatok szerint elhanyagolható. A lövedékek standard vizsgálatok során alkalmazott elméleti tulajdonságait az 1. táblázat tartalmazza, méretüket és alakjukat az 5. ábra és a 6 . ábra mutatja.

A vizsgálatok során a lövedékek kilövése kilövőbakról (7(a) ábra), a céllemezektől kb. $6.7 \mathrm{~m}$ távolságból történt. A lemezeket függőleges helyzetben egy keretbe rögzítettük, amely négy él mentén nyújtott megtámasztást a lemeznek (7(b) ábra). A lövedék a lap felületére merőlegesen csapódott be.

A próbák során fotocellás fénykapuk, illetve ballisztikai analizátor segítségével mértük és rögzítettük minden egyes lövés lövedékének sebességét (8. ábra). Minden lövést követően lemértük a bemeneti oldalon a penetráció mélységét $(x)$, illetve a kimeneti oldalon, varasodás esetén, a kráter legnagyobb mélységét $\left(x_{\mathrm{s}}\right)$, valamint fényképen rögzítettük a bemeneti és kimeneti oldalt. Kiegészítő vizsgálatként néhány mérés esetén ben a táblákat laboratóriumi hőmérsékleten tároltuk és egy héten keresztül műanyag fóliával borítottuk. A kizsaluzás egynapos korban történt.

A lőtéri próbákat a Magyar Honvédség Logisztikai Központ Lőkísérleti és Vizsgáló Alosztályon, Táborfalván végeztük, kültéren, napos időben, a léghőmérséklet $25^{\circ} \mathrm{C}$ volt. nagy sebességü kamera segítségével is felvettük a becsapódás és a varasodás folyamatát (9. ábra). A vizsgálat módjáról néhány átnézeti képet mutat a 10. és 11. ábra.

A lőtéri próbák során minden betonlemezbe 3-3 lövést végeztünk .44 Magnum (1-3. sz. lövés) és 12/70 Brenneke (4-6. sz. lövés) lövedékkel. A próbák során nem minden 


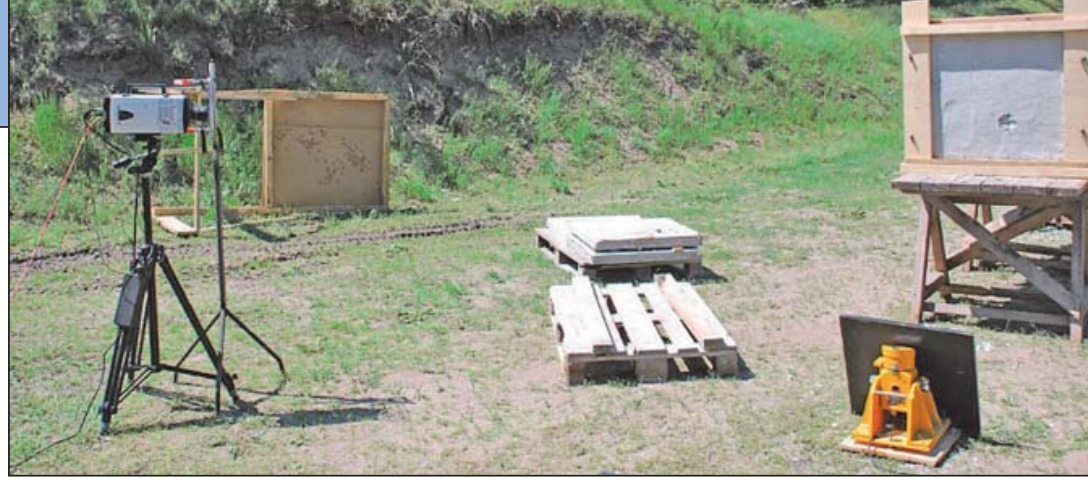

9. ábra. Nagy sebességú kamera egy pozíciója

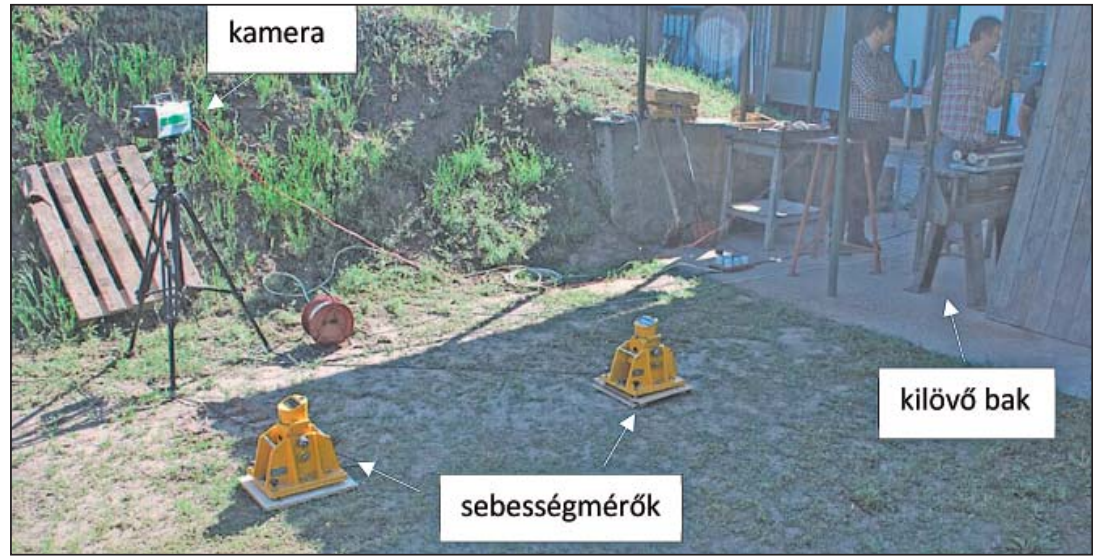

10. ábra. Fotocellás sebességmérők, nagy sebességű kamera és kilövő bak helyzete

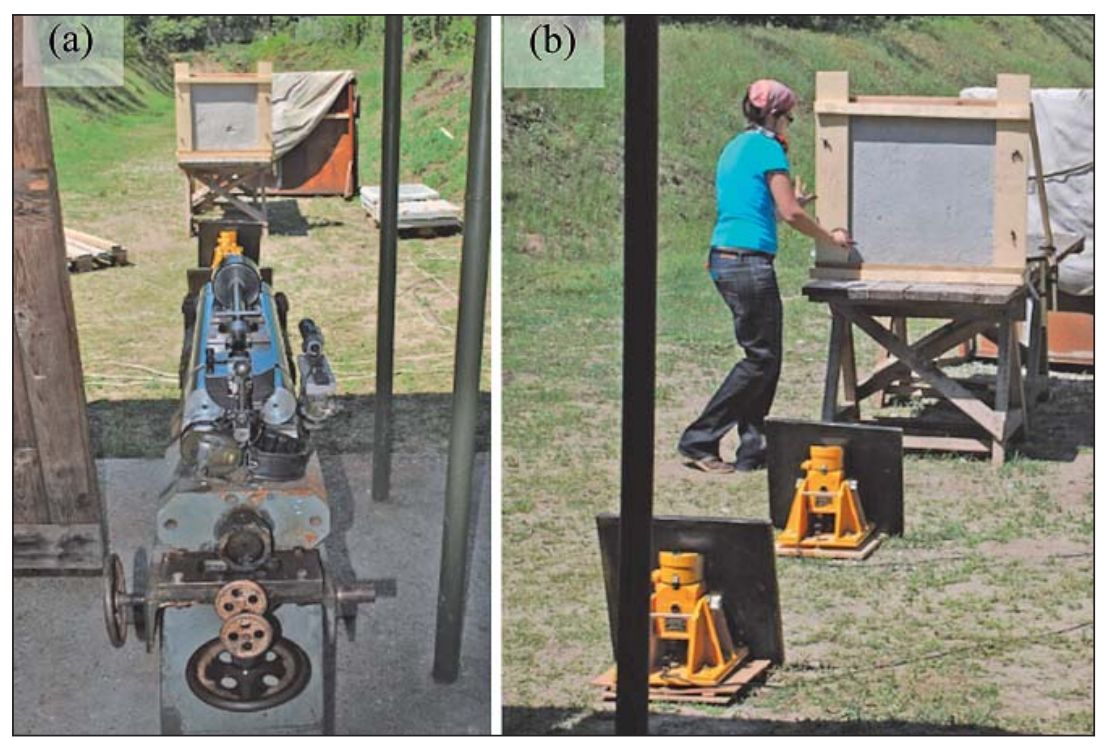

11. ábra. Két átnézeti kép a vizsgálatról (a) a kilövő bak mögül, (b) illetve oldalról

12. ábra. (a) .44 Magnum és (b) 12/70 Brenneke lövedékek maradványa az ütközést követően

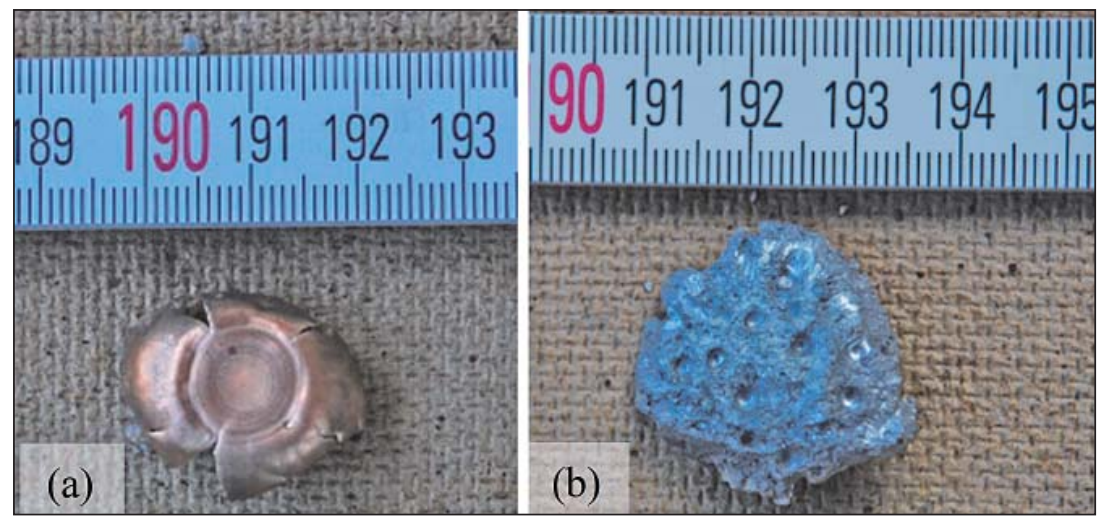

esetben történt sebességmérés. Ennek oka, hogy a változó fényviszonyok miatt a sebességmérő cellák nem minden esetben tudtak sebességértékeket rögzíteni, az 54 lövésből, 38 esetben kaptunk értékelhető sebességeredményt. Az érvényes méréssel rendelkező lövések statisztikai értékelésekor a sebességek átlagtól való átlagos abszolút eltérése $1,71 \%$, illetve 1,01\% a két lövedéktípus esetében, így az átlagérték (.44 Magnum esetén 392,1 m/s, 12/70 Brenneke esetén $429,0 \mathrm{~m} / \mathrm{s}$ ) jól reprezentálta a mintát. Feltételezhető, hogy a nem mért sebességek sem mutatnának jelentős eltérést az átlagértéktől. A mért sebességek eltérnek az a 1. táblázat szerinti szabványos értékektől, ennek az az oka, hogy előre töltött lövedékeket alkalmaztunk, ennek megfelelően a próbák nem tekinthetőek standard próbának, ugyanakkor a hatások vizsgálatának szempontjából ez nem volt elvárás.

A lövések során az ólom anyagú lövedékek szétkenődtek, majd visszapattantak a lemezekről. A 12. ábra a .44 Magnum, illetve a 12/70 Brenneke esetén mutat egy-egy megmaradt lövedékdarabot. A 12/70 Brenneke lövedék esetén az ólomba benyomódott acélsörét adalékanyag nyomai is látszanak, míg a .44 Magnum esetében csak a rézköpeny maradt meg a lövedékből.

A .44 Magnum lövedék esetén, a cementpép (NCO) esetét leszámítva, nem alakult ki varasodási kráter a lemez hátsó felületén. A 12/70 Brenneke esetén a lövések túlnyomó részében kialakult varasodási kráter. Néhány reprezentatív károsodási módot mutat be a 13. ábra és a 14. ábra.

Az alkalmazott hálós vasalás a lövedékkel szembeni ellenállásban is szerepet játszik, a szakirodalmi eredmények alapján a penetrációt kis mértékben, a perforációt és a varasodást jelentősebben befolyásolhatja, mivel a varasodási kráter méretét megnöveli. Mivel minden keverék esetén azonos vasalást alkalmaztunk, így a vasalás hatása egyformán játszik bele a mért eredményekbe, az eredmények tendenciái azonban elsősorban a beton anyag miatti viselkedést mutatják.

\subsection{LABORATÓRIUMI VIZSGÁLATOK}

A lőtéri próbák mellett laboratóriumi kísérletekre is sor került, amelyek során a beton nyomószilárdságát $(f)$ határoztuk meg az MSZ EN 12390-3:2009 szabvány szerint. A keverékenként 3-3 db, $150 \times 150 \times 150$ mm-es kockán $v=11,25 \mathrm{kN} / \mathrm{s}$ terhelési sebességgel végzett nyomószilárdsági próbákat 


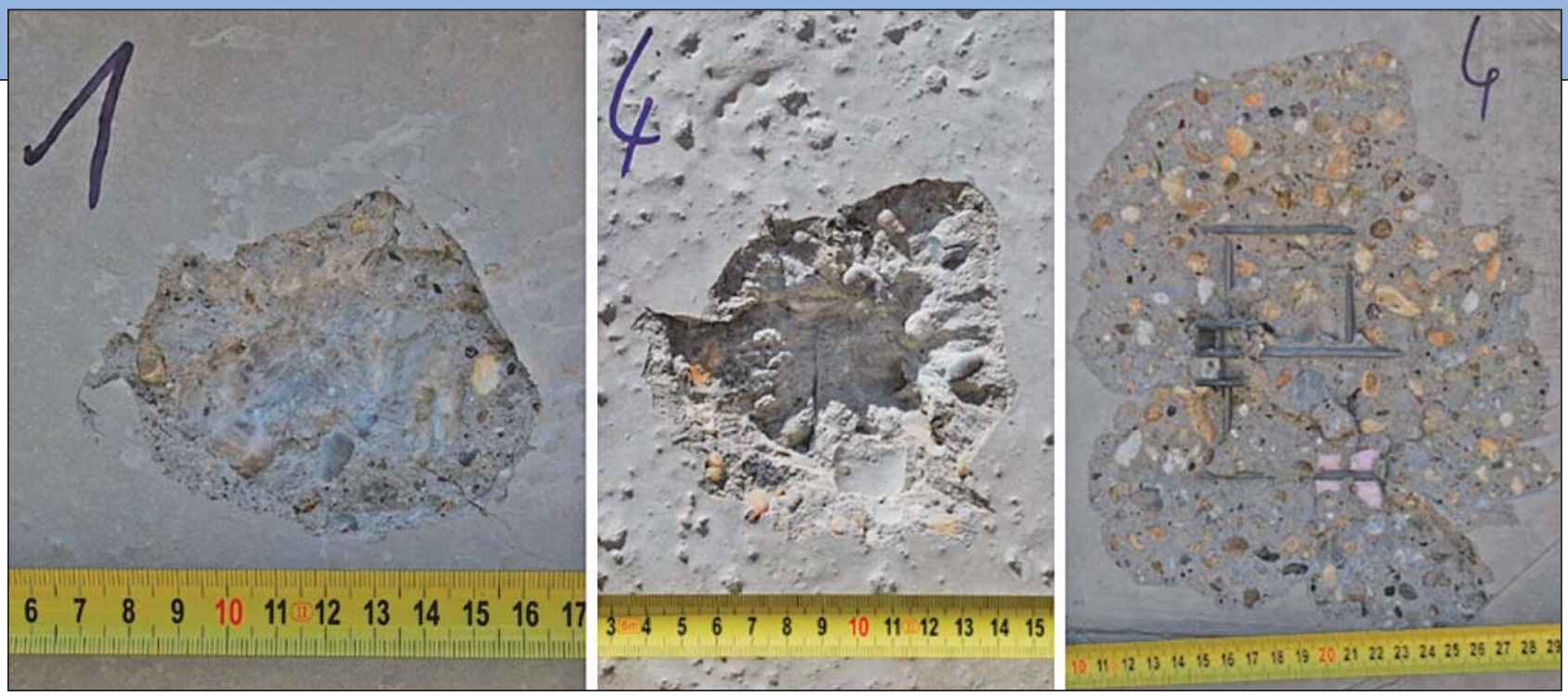

13. ábra. SCC16 keverék (balról jobbra): penetráció (.44 Magnum), penetráció (12/70 Brenneke) és varasodás (12/70 Brenneke)

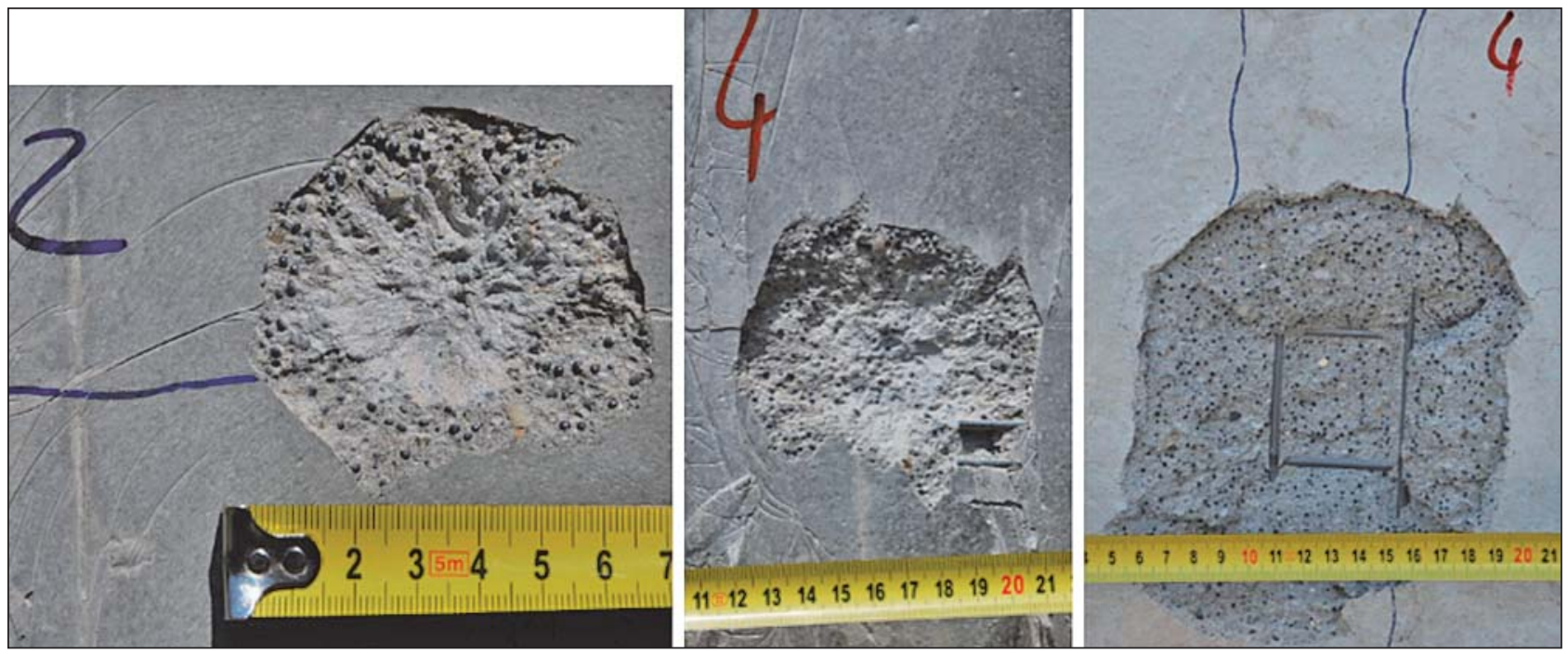

14. ábra. HWC4 keverék (balról jobbra): penetráció (.44 Magnum), penetráció (12/70 Brenneke) és varasodás (12/70 Brenneke)

(A számok a 13-14. ábrán a lövés sorszámát jelezték, így például a 4 szám az adott táblába a végzett 4 . lövést jelenti. Az 1-3. számok .44 Magnum, a 4-6. számok 12/70 Brenneke lövedékkel végzett lövéseket jelöltek.)

15. ábra. Nyomószilárdság mérése a BME Építőanyagok és Magasépítés Tanszék laboratóriumában

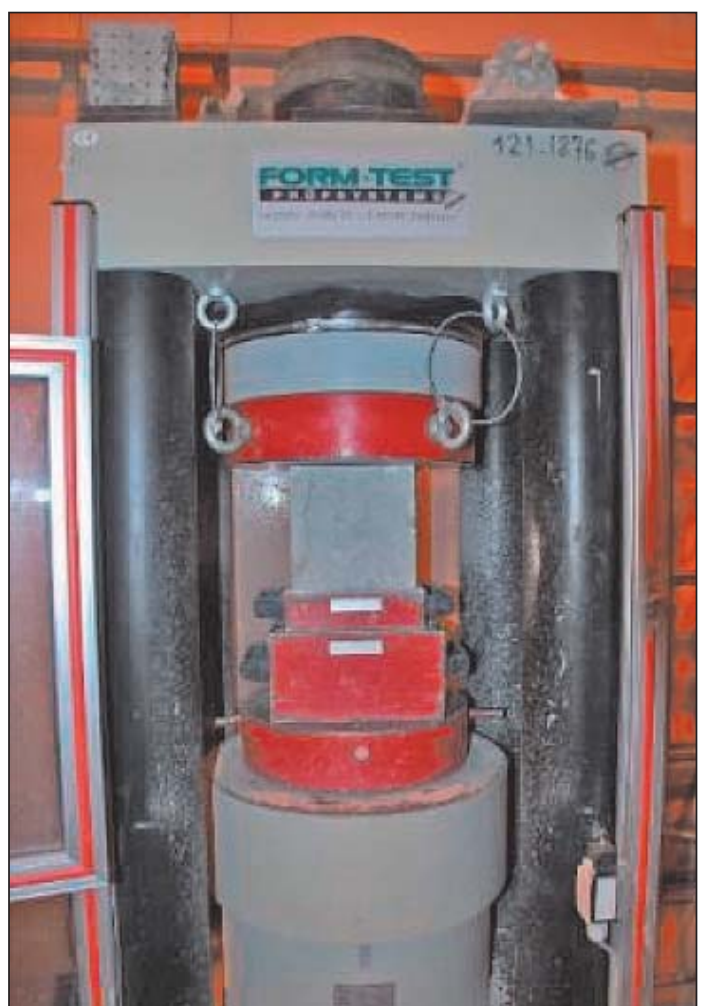

FORM TEST ALPHA 3000 akkreditált nyomószilárdság-mérő segítségével végeztük el (15. ábra), a BME Építőanyagok és Magasépítés Tanszék laboratóriumában. A laboratóriumi kísérletekre a lőtéri próbákkal egy időben, a beton 200 napos korában került sor. Ennek megfelelően, a mért szilárdságértékek nem a 28 napos szabványos szilárdságot, hanem a kísérletkori valódi kockaszilárdságot mutatják. A mért nyomószilárdsági értékek átlagtól való átlagos eltérése az NC0 keverék esetén 5,66\%, a több keveréknél 1,01-1,89\% közötti volt, így a keverékek minősége egyenletes, a szilárdság átlagértéke jól reprezentálja a keveréket.

1. táblázat. Alkalmazott lövedékek elméleti tulajdonságai

\begin{tabular}{|l|c|c|}
\hline & .44 Magnum & 12/70 Brenneke \\
\hline tömeg [kg] & 0,01555 & 0,028 \\
\hline torkolati sebesség [m/s] & 420 & 416 \\
\hline mozgási energia [J] & 1371,51 & 2422,78 \\
\hline átmérő [mm] & 11,17 & 18,4 \\
\hline jellemzők & ólom, tompa orr & $\begin{array}{c}\text { ólom, hasított } \\
\text { rézköpeny, tompa orr }\end{array}$ \\
\hline
\end{tabular}




\subsection{AZ EREDMÉNYEK ÉS ÉRTÉKELÉSÜK}

Keverékenként az átlagos nyomószilárdság, illetve a penetrációs mélységek és a varasodási krátermélységek közti összefüggést a 16. ábra és 17. ábra mutatja be. A 16. ábra alapján a cementpép (NCO) keverék mind szilárdságban (34,7 MPa), mind a lövedékkel szembeni ellenállásban lényegesen gyengébb, mint a többi keverék, amelyek nyomószilárdsága 60-75 MPa között változott. A varasodási krátermélység-értékek alakulása nem mutatott egyértelmű tendenciát a nyomószilárdság függvényében. A 17. ábrán a mért nyomószilárdság-penetrációs mélység értékekre lövedéktípusonként lineáris függvényt illesztettünk, amiket a szaggatott egyenesek mutatnak.

A 17. ábra több érdekességet is mutat a penetrációs mélység és a nyomószilárdság összefüggése esetén. Az ábrán szaggatottan bekeretezett értékek olyan eseteket mutatnak, amikor a nagyobb nyomószilárdsághoz nagyobb penetrációs mélység, tehát kisebb lövedékkel szembeni ellenállás tartozott. Ez a tendencia többször jelentkezett a nagyobb lövedékátmérőjű 12/70 Brenneke esetén, amelynek mérete közelebb van az adalékanyag maximális szemnagyságához. Látható, hogy a nagyobb szemnagyság (az NC8 keverékhez képest az NC16 keverék, a HWC4 keverékhez képest a HWC8 keverék, az SCC8 keverékhez képest az SCC16 keverék) esetén nagyobb nyomószilárdság kisebb penetrációval szembeni ellenállással járt. Ez azt mutatja, hogy a statikus nyomószilárdság szempontjából kedvezőbb nagyobb szemnagyság, a dinamikus penetráció szempontjából nem előnyös. Ez vélhetően amiatt van, hogy a kisebb adalékanyag-szemcséken dinamikus (ütközési) teher esetén a repedés áthalad, így azok nagyobb ellenállása kedvezően kifejti hatását, míg a nagyobb szemcséknél a repedés inkább megkerüli a szemcsét, így az adalékanyag 2. ábra szerinti kedvező hatása nem tud érvényesülni. Szintén látszik az ábra alapján, hogy a HWC nehézbeton-keverékek viselkedése a nyomószilárdságukhoz képest kedvezőbb, mint a kavics adalékanyagú keverékeké. Ennek lehetséges magyarázata lehet, hogy az acélsörét-szemcséket a repedések megkerülik, így a repedéshosszúság jelentősen megnő, ami megnöveli az ellenállást is. A kapott eredmények alapján látható, hogy a penetrációval és perforációval szembeni ellenállás csak nyomószilárdság alapú számítása pontatlan lehet, nem láthatók egyértelmű trendek. Levonható a következtetés, hogy az adalékanyag

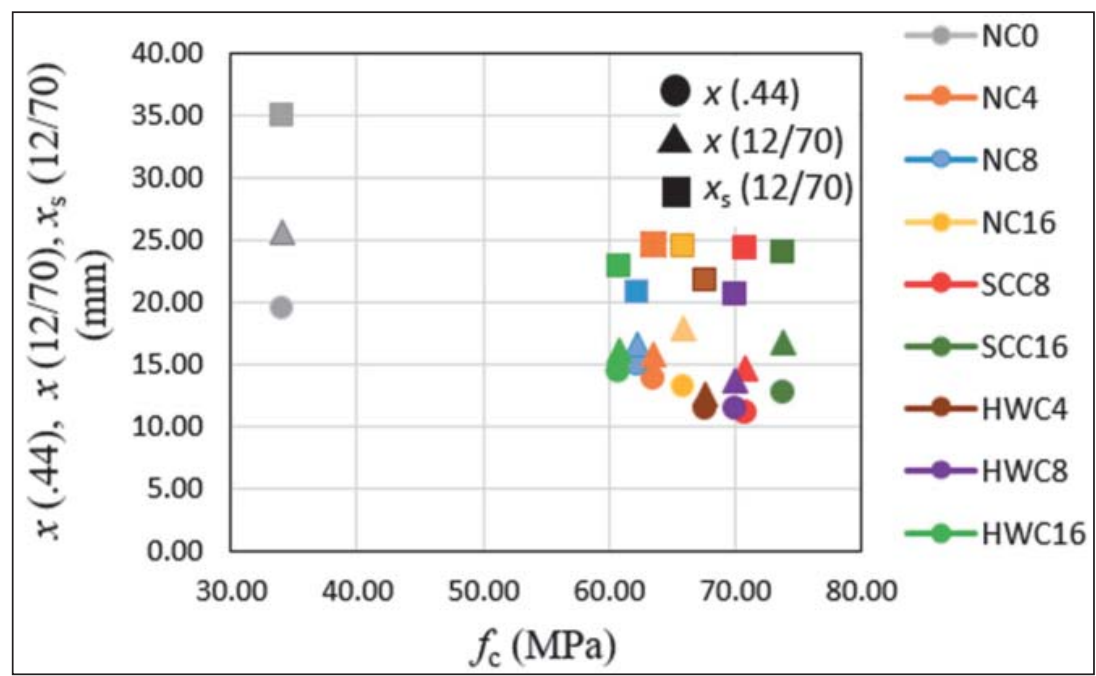

16. ábra. Penetrációs $(x)$ és varasodási krátermélység $\left(x_{s}\right)$ a nyomószilárdság függvényében (.44 Magnum, és 12/70 Brenneke, a pontok 3-3 mérés átlagát jelentik)

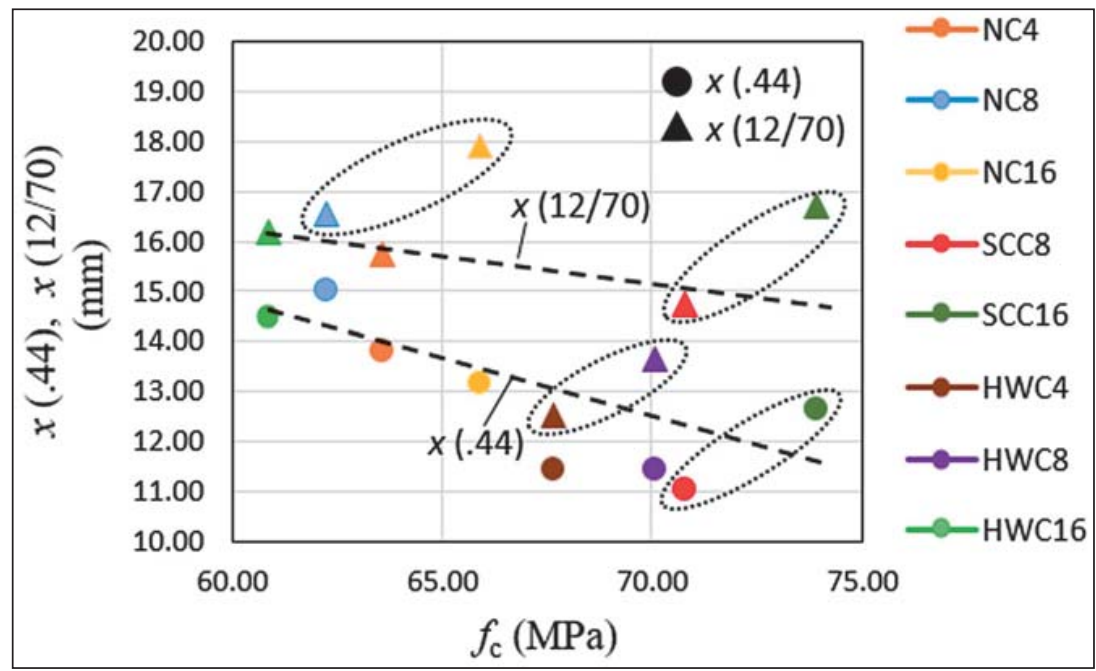

17. ábra. Penetrációs mélység a nyomószilárdság függvényében (.44 Magnum, és 12/70 Brenneke, a pontok 3-3 mérés átlagát jelentik, a szaggatott egyeneseket a lövedéktípusonként kapott eredményekre illesztettük)

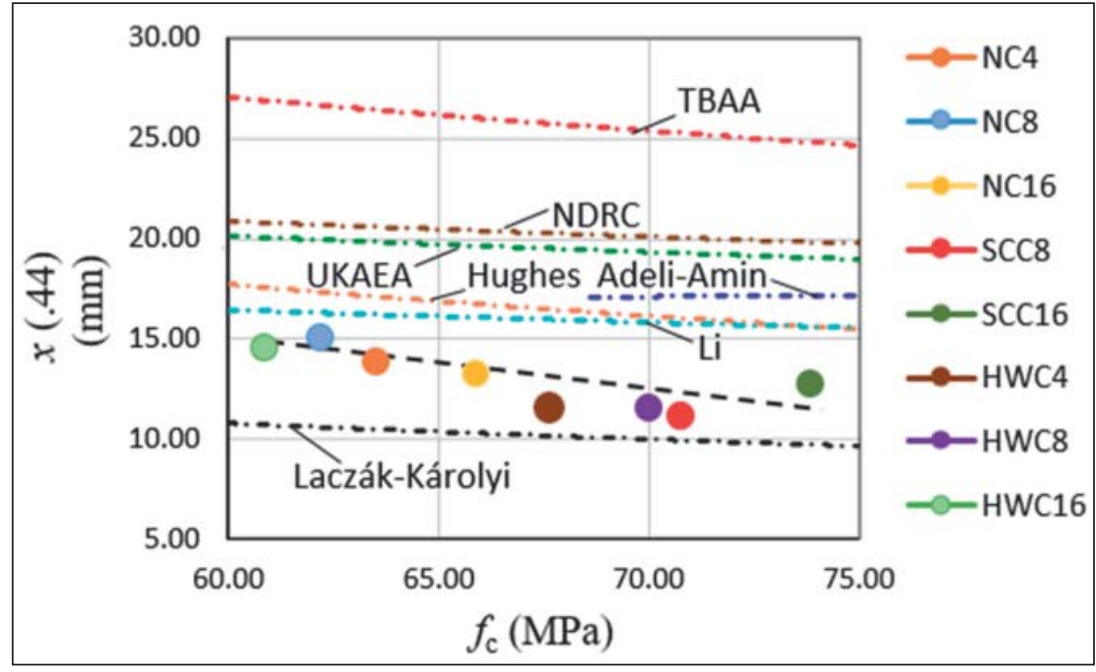

18. ábra. Penetrációs mélység a nyomószilárdság függvényében, .44 Magnum esetén (a mért értékek átlagain és a rájuk illesztett egyenesen kívül különböző félempirikus formulák eredményei láthatóak) 


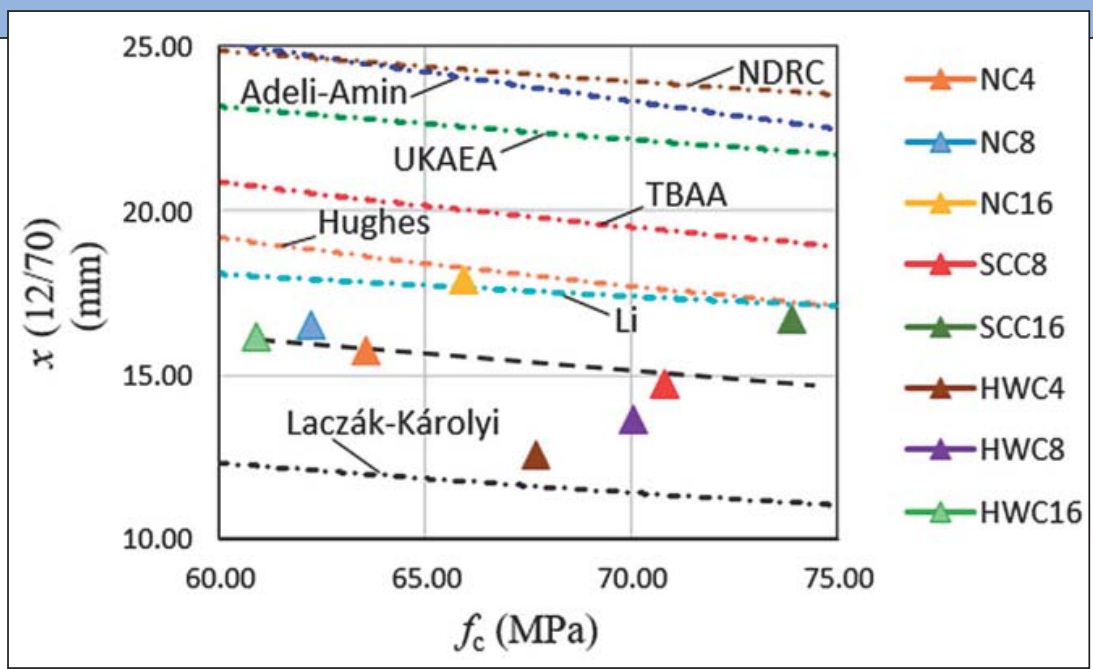

19. ábra. Penetrációs mélység a nyomószilárdság függvényében, 12/70 Brenneke esetén (a mért értékek átlagain, és a rájuk illesztett egyenesen kívül különbözó félempirikus formulák eredményei láthatók)

típusa és szemnagysága nem csupán a nyomószilárdságon keresztül befolyásolja az ellenállást.

A mért penetrációs mélység értékeket összevetettük több, a szakirodalomban [Kennedy (1976), Teland (1998), Li és társai (2005), Murthy és társai (2010), Laczák és Károlyi (2016)] található számítási formula eredményeivel (18. és 19. ábra).

Az ábrákon látható, hogy a különböző formulák eredményei jelentősen eltérnek egymástól, ez a képleteket megalapozó kísérletsorozatok eltéréseiből ered. Mindkét lövedék esetén a mérési eredményeink Li (Li és társai [2005]) és Laczák-Károlyi (Laczák és Károlyi [2016]) formuláival kapott eredmények közé estek. Megjegyezzük, hogy a számítási formulák tökéletesen kemény lövedékekre vonatkoznak, így azokat a valós kísérletben látott lövedékdeformációk (12. ábra) miatt módosítani kellene. Az azonban így is látható, hogy a számítási formulák a szűk nyomószilárdság tartományon közelítőleg lineáris eredményt adnak, amitől a mért értékek jelentősen eltérnek. Ez szintén azt erősíti meg, hogy a nyomószilárdságon kívül célszerü lehet az adalékanyag jellemzőit is figyelembe venni a penetrációs mélység számításakor.

\section{ÖSSZEFOGLALÁs}

A kísérletsorozatban a beton adalékanyagának hatását vizsgáltuk kemény lövedék becsapódása esetén. Laboratóriumi és lőtéri kísérleteket hajtottunk végre kilenc különböző keveréken, amelyek elsősorban az adalékanyag típusában (kvarckavics, illetve acélsörét), valamint maximális szemnagyságában tértek el. Vizsgáltunk normálbeton, öntömörödő beton, illetve nehézbeton keverékeket.

A lőtéri próbák során mért penetrációs mélység kedvezőtlenebb volt a nagyobb nyomószilárdságú SCC16 $\left(d_{\max }=16 \mathrm{~mm}\right)$ öntömörödő betonkeverék esetén, mint a kisebb szilárdságú SCC8 esetén, mind .44 Magnum, mind tási modellek módosításához további kísérletsorozat végrehajtása és azok kiértékelése szükséges.

Köszönetnyilvánítás: A lőtéri kísérletek elvégzésében Lajosbányai István alezredes, a Magyar Honvédség Logisztikai Központ Lőkísérleti és Vizsgáló Alosztály alosztályvezetője és kollégái vettek részt, akik idejüket nem kímélve segítették a kísérletek előkészítését és megvalósítását. A lőszerek egy részét Miskovics György, a Harmónia $91 \mathrm{Kft}$ ügyvezető igazgatója biztosította. A kutatást a Nemzeti Erőforrások Minisztériuma Új Nemzeti Kiválóság Programja támogatta.

\section{HIVATKOZÁSOK}

Kennedy, R. P.: A review of procedures for the analysis and design of concrete structures to resist missile impact effects. Nuclear Engineering and Design. 37:183-203. (1976);

Laczák, L. E., Gy. Károlyi: Local Effects of Impact into Concrete Structure. Periodyca Polytechnica Civil Engineering 60:573-582. (2016);

Li, Q.M., S.R. Reid, H.M. Wen, A.R. Telford: Local impact effects of hard missiles on concrete; targets. International Journal of Impact Engineering 32:224-284. (2005);

Murthy, A. R. C., G. S. Palani, N.R. lyer: Impact Analysis of Concrete Structural Components. Defense Science Journal 60:307-319. (2010);

Teland, J. A.: A review of empirical equations for missile impact effects on concrete. Report no. FFI/RAPPORT-97/05856, Norwegian Defence Research. Establishment, Kjeller. (1998);

Zielinski, A.J.: Concrete structures under impact loading. Rate effects, Report 5-84-14, Research No. 2.3.84.07., Delft University of Technology, Department of Civil Engineering, Delft. (1984).

\section{Helyreigazítás}

A Haditechnika 2017/6. számában megjelent „Szemelvények a katonai-víztisztítási kutatásokból III. rész” című cikk első mondatában a „Központi Környezet- és Élelmiszer-tudományi Kutató Intézet” a cikk által vizsgált időszakban helyesen „Központi Élelmiszeripari Kutató Intézet” volt. A 15. ábra feliratában hibás az irodalomhivatkozás, ez helyesen az alábbi: [11.]

Ugyanebben a lapszámban „A SAAB J-29 Tunnan svéd gázturbinás harcirepülőgép I. rész” c. cikkben a „kristálydetektoros rádió” hibás fordítás eredménye. Az FR-8 (FR-8/4 és FR-8/10) típusú „kristallstyrd” rádió helyesen: kristályvezérelt. (Egy kristály volt beépítve minden egyes csatorna számára.) A Haditechnika korábbi számának recenziójában ismertetett „Elhurcolva - távol a hazától” c. könyvet a Zrínyi Kiadóban, a Kerepesi úton nem lehet megvásárolni, mivel nem ez a kiadó adta ki, hanem a Hadtörténeti Intézet és Múzeum. 